\title{
Institutions and intellectual property: the case of software industry in Brazil
}

\begin{abstract}
This study contributes to the analysis of institutional change, considering the conditions in an organizational field and the position held by institutional entrepreneurs. We studied the case of the change in intellectual property rights in Brazil in the 80's and 90 's decades of the last century. Data sources were interviews and document research that were analysed on their content. The examination of the process of institutional change on intellectual property of software revealed a complex interaction between two organizational fields, one local and another global. Initially protected from external threats by a market reserve policy, the local organizational field legitimated practices that have been condemned in the global organizational field. We concluded that multiple and contradictory institutions favoured the emergence of the institutional change as well as agency of powerful actors at the centre of the global organizational field.
\end{abstract}

Keywords: institutional entrepreneurship, organizational institutionalism, institutional change, organizational field, software industry, intellectual property
Volume 3 Issue I - 2019

\author{
Artur Jacobus, Yeda Swirski de Souza \\ Department of Business and Management School, Unisinos \\ Business School, Brazil
}

\begin{abstract}
Correspondence: Artur Jacobus, Department of Business and Management School, Unisinos Business School, Brazil, Tel + 555I-35915000,Email yedasou@unisinos.br
\end{abstract}

Received: October 17, 2017 | Published: February 01, 2019

\section{Introduction}

This study contributes to the analysis of the mutual influence between organizations and institutions, placing special attention on the processes of institutional change in an organizational field. The purpose is to investigate to what extent institutional entrepreneurship plays a role on the change of a formal institution as the intellectual property rights. Based on the evidence of the change in intellectual property rights in Brazil in the 80 's and 90 's, this study intends to characterize some of the features of the actors influencing institutional change, considering the following: (a) the conditions in an organizational field (b) the position held by institutional entrepreneurs in an organizational field.

We consider the evolution of intellectual property rights in the software industry in Brazil as an exemplar case to offer insights on the interplay between public and private sectors and national and international actors in the establishment of the rules of the game to be played in an industry. The Brazilian software industry is one of the largest in the world. ${ }^{1}$ This industry has experienced significant institutional changes since it came into existence as a separate sector. Entrepreneurs and leaders of industry associations recognize that changes in the law on intellectual property rights represented a significant institutional change that transformed the landscape of the industry. In the early 80 's, there was no specific legislation on intellectual property for software production in Brazil. Furthermore, Brazil had adopted a policy at the time to protect the domestic IT industry, severely restricting production, and commercialization of software by foreign companies. However, less than 20 years later, the country began to adopt legislation that ceased to treat domestic firms differently to foreign ones and that began to recognize intellectual property rights for software production.

We analyze the interplay between the features of the organizational field and the actions of the institutional entrepreneurs that had been favoring or constraining changes in intellectual property rights. We considered the organizational institutionalism approach with emphasis on studies on institutional entrepreneurship to analyze the processes of institutional change in the context of the software industry in Brazil. The perspective of institutional entrepreneurship explores the proactive role of individuals and organizations to create and transform institutions. ${ }^{2-5}$ The most vivid of these issues that have been evolving in the last decades in studies about institutional change and institutional entrepreneurship explores the conditions that allow certain organizations, individually or collectively, to shape the institutions based on their interests and needs. Nevertheless, studies on institutional entrepreneurship are not conclusive about who are, within an organizational field, the players most likely to promote institutional change. On the one hand, one of the requirements of the institutional entrepreneur is to have access to sufficient resources to enable the desired change. ${ }^{6}$

Also, Colomy ${ }^{3}$ and Fligstein ${ }^{4}$ correlate the chance of success of a project of institutional change to the amount of resources available to its protagonists. Contrastingly, there are authors who see in peripheral actors, the parties with a major interest in change because the institutional arrangements usually tend not to serve them with priority. ${ }^{5,7}$ Thus, an issue of great importance is to conduct empirical studies to identify if there is indeed room for peripheral actors to succeed in institutional entrepreneurship actions. Based on the evidence of the change in intellectual property rights in Brazil in the 80 's and 90 's, this study intends to characterize some of the features of the actors influencing institutional change, considering the following: (a) the conditions in an organizational field (b) the position held by institutional entrepreneurs in an organizational field. ${ }^{5}$ In the next section, we present the approach of institutional entrepreneurship we adopted in this study and the categories applied to analyze the empirical evidence. We then describe the methodology used in this study and present the case of the evolution of intellectual property rights in the Brazilian software industry. The analysis emphasizes the characterization of the organizational field, its actors, and their motivations and positions. Finally, we present the conclusions of this study. 


\section{Perspectives on Institutional Change and Institutional Entrepreneurship}

To support the analysis about the mutual influence between organizations and institutions in the case of intellectual property evolution in software industry in Brazil, we assume a role for agency in institutions structuration and we highlight two aspects in the studies of institutional change and entrepreneurship: (a) the conditions of an organizational field; (b) the position held by institutional entrepreneurs in an organizational field. ${ }^{5}$ Institutions if conceived as ways of representing, reflecting, and enacting social reality, that tend to gain stability from its continuous reproduction in society promotes imply on a view of individuals conditioned by institutions. The structuration theory tries to offer a different view. Under this theory, in the one hand "the rules and resources outlined in the production and reproduction of social action are at the same time the means of system reproduction". ${ }^{9}$ This structure is manifested in the form of habits and routinesinstitutions, therefore-which are enabling or coercive because they can favor or constrain action. In the other hand, human action is not pure script execution: there is also room for strategic choices-so, for the agency-which ends up forming, along with the structure, a duality. ${ }^{10}$ In accordance with the conception of Veblen ${ }^{11}$ on institutions, human action is at the same time constrained by institutions, but also able to transform them. Consequently, routinized practices are not absolute; allow some level of choice that is the seed of its transformation. This perspective on the relationship between institutions and organizations relativizes the coercive power of the institutions.

Align to the structuration theory view, institutionalism in organizational studies has been changing from a perspective that sought to explain convergence, conformity, stability, passivity, and homogeneity of actors to a perspective related to divergence, dissension, instability, proactivity, and heterogeneity of actors. ${ }^{12} \mathrm{~A}$ growing number of scholars began to examine the institutions and, even recognizing its stabilizing trend, began to look for explanations for the process of creation, change or dissolution of institutions and, consequently, deserving some room for human and organizational action in the processes of institutional change. , $^{5,67}$

This new focus on the relationship between institutions, individuals, and organizations, that leaves room for notions of agency and interest, converged around the concept of "institutional entrepreneurship". This expression relates to the "activities of actors who have interest in particular institutional arrangements and who leverage resources to create new institutions or to transform existing ones". ${ }^{13}$ Originally conceived by Eisenstadt, ${ }^{14}$ the concept of "institutional entrepreneurship" reached resonance from a seminal paper of DiMaggio ${ }^{6}$ and proposes that the research in the area should also pay attention to the processes of institution building and institutionalization. DiMaggio ${ }^{6}$ statement that the creation of new institutions is costly and requires high levels of interests and resources has been supporting investigation about the creation of institutions. In parallel, research in the field of institutional entrepreneurship has been gradually contributing to the knowledge about institutional changes, i.e., not in the creation of something entirely new, but on transformation of what already exists. Studies on institutional entrepreneurship analyses the apparent contradiction between institutions that influence individuals, and the existence of individuals who, freed of this conditioning, visualize the possibility of transforming these institutions. In the following paragraphs, we highlight some aspects related to institutional entrepreneurship opportunities that were insightful for analyze the case of evolution on intellectual property in the software industry. Nonetheless, studies on this field propose other aspects that are not mentioned here due to limitations on scope of this study.

\section{Conditions of the organizational field}

One aspect to be considered in examining processes of institutional change are conditions of the organizational field as they can be favorable or inhibit actions of institutional entrepreneurship. Institutional change motivations for has been explained by future uncertainty that requires adaptation as well by existing tensions and contradictions in highly institutionalized fields. ${ }^{5}$ Among the stimuli that promote institutional change is uncertainty, or, as say Pfeffer $\&$ Salancik ${ }^{15}$ the degree to which future states of the world cannot be accurately predicted or anticipated". If institutions, as stated by economists such as Veblen \& Williamson, ${ }^{11}$ play the role of making the behavior of actors more predictable, then a scenario of uncertainty favors the adoption of an institutional solution that reduces the unpredictability that characterizes an organizational field at a given time.

Regarding the role of tensions and contradictions in the organizational field, it has been recognized that behind the apparent stability of organizational fields, of socially negotiated consensus, underlying differences can occur mature fields. ${ }^{5,16}$ Incompatibility between legitimacy and efficiency in one of the sources of contradiction ${ }^{17}$ and already explored in seminal studies about organizational institutionalism..$^{18,19}$ Conformity to institutional arrangements may generate legitimacy under the cost of a level of inefficiency that encourages certain actors to seek new arrangements more favorable to the sustainability of their organizations. The contradiction can also arise when adapting to institutional rules puts at risk the adaptive capacity of organizations. Blind acceptance of rules and norms may lead, over time, to the inability to perceive deficiencies in the present institutional arrangement, preventing actors from seeing better alternatives. ${ }^{17}$

Another potential source of contradiction exists in the clash between compliance with an institutional arrangement at a level or sector with arrangements of other levels or sectors. An example cited by Seo \& $\mathrm{Creed}^{17}$ concerns the importance of the family in capitalist markets, that helps to reduce labor costs but, at the same time, is a victim of practices in the same market. Additionally, contradiction can still originate from a conflict between isomorphic tendencies and divergent tendencies, what is related to the level of power of the different actors. Existing institutional arrangements would tend to reflect the interests of actors with more political power, that would hardly satisfy all actors in the organizational field, especially the less powerful actors. ${ }^{17}$ Thus, actors who are not being adequately served by the existing institutional arrangement would be those who, under certain circumstances, will become aware of the constraints imposed on them by the current institutional setting and become agents of change.

\section{Position of institutional entrepreneurs in an organizational field}

Another aspect considered when examining processes of institutional change is the positions held by institutional entrepreneurs. The concept of "position" is associated with the concept of organizational field. Organizational field is defined as "a community of organizations that partakes a common meaning system and whose participants interact more frequently and fatefully with one another 
than external with actors outside the field". ${ }^{20}$ An organizational field may comprise companies, government, business associations, professional associations, interest groups and other stakeholders. More than a group of influential organizations, the organizational field is a common space for dialogue and discussion around relevant issues for all its members. ${ }^{21}$ Within a field, there are a limited number of positions to be occupied, from which the actors can act. ${ }^{5}$ Power relations between the actors participating of an organizational field depend on these positions, that are associated with different amounts of resources (including capital). Relationships and resources of the actors of the field give them different interests and opportunities, and, depending on the circumstances, the possibility of exercising power over that field at a given time. ${ }^{5,22}$ Per this vision, the power the actors may have is related to the positions they occupy in organizational field and at a specific time. The concepts of center and periphery designating a hierarchy of positions have been employed in the institutional entrepreneurship approach. Greenwood \& Suddaby ${ }^{7}$ propose that these two notions include the ability of the central actors in a social structure to establish an institutional logic favorable to their interests as well as acceptance of this logic as given by the different members of the organizational field.

One implication of the concepts of center and periphery to designate a hierarchy of positions is to investigate the correlation between position in an organizational field and protagonism in institutional entrepreneurship actions. A common-sense assumption is to expect that central actors would act to keep the institutional framework aligned to their interests. Nevertheless, studies on this subject show that both central and peripheral actors play impactful roles in institutional entrepreneurship. The explanations given to the initiatives of central positioned actors refer to the interaction of these individuals or organizations with other institutional arrangements (e.g., multinationals that operates in different countries with different institutions). But there is evidence that peripheral actors can promote institutional change. Per Greenwood \& Suddaby, ${ }^{7}$ Hardy \& Maguire, ${ }^{5}$ there is greater ease for peripheral actors to develop ideas for change because:

a) They would be less connected to other actors, and therefore less aware of institutional norms and practices; and

b) Because they would be more exposed to alternative ideas by being positioned away from the center of the organizational field

The position of peripheral and unsuccessful actors in institutional entrepreneurship initiatives is also advocated by Seo \& Creed, ${ }^{17}$ but the authors themselves recognize that institutionalism has traditionally privileged the actions of actors who have access to more resources. Table 1 summarizes elements about conditions of an organizational field and position of institutional entrepreneurs that will favor the analysis of the case of the evolution of intellectual property rights in the software industry in Brazil. In the next section, we present the method used to conduct the research.

Table I Institutional Change: explicative elements

\begin{tabular}{|c|c|}
\hline & Explanation \\
\hline \multirow[t]{6}{*}{$\begin{array}{l}\text { Condition of the } \\
\text { organizational field }\end{array}$} & Uncertainty: \\
\hline & $\begin{array}{l}\text { - Institutional change can reduce the unpredictability of an organizational field. (Pfeffer \& Salancik, 2003; Hardy and Maguire, } \\
\text { 2008). }\end{array}$ \\
\hline & Tensions and Contradictions: \\
\hline & - Incompatibility between legitimacy and efficiency (Meyer and Rowan 1977, DiMaggio, and Powell, I983). \\
\hline & -Clash between institutional compliance and organizational level (Seo and Creed, 2002). \\
\hline & $\begin{array}{l}\text {-Conflict between isomorphic tendencies and divergent tendencies related to the level of power of the different actors (Seo } \\
\text { and Creed, 2002). }\end{array}$ \\
\hline \multirow[t]{2}{*}{$\begin{array}{l}\text { Position of the actors in } \\
\text { the organizational field }\end{array}$} & Center and Periphery: \\
\hline & $\begin{array}{l}\text {-Center and periphery designate a hierarchy of positions of institutional actors on their condition of establishing an } \\
\text { institutional logic favorable to their interests (Greenwood and Suddaby, 2006). }\end{array}$ \\
\hline
\end{tabular}

\section{Method}

This study adopts a qualitative research method, following a trend in studies in the organizational institutionalism field. ${ }^{23-25}$ Qualitative research is appropriate to the purpose of this research, that aims to understand a process of institutional change, from inception to achievement. Thus, it is necessary to seek the origins of the change process, and then track its deployment, identifying actors, resources, motives, and strategies. The analysis of data cares about confronting evidence and interpretation to existing theoretical conceptions. We adopted a diachronic perspective to reconstruct historically the process, following a trend of most studies about the relationship between organizations and institutions. ${ }^{25,26}$

The process of institutional change we analysed can be divided into two stages that are aligned with changes in the legislation on intellectual property rights in the software industry in Brazil. The different laws about intellectual property rights modified the "game rules" of the industry, favoring certain groups over others. We took these two stages as boundaries to describe the change process. We also followed what has been usual on the reconstruction of institutional entrepreneurship episodes, considering basically two sources of data: documents and testimonies of actors in the process. ${ }^{25}$ 
The research plan envisaged sources of primary data basically collected through interviews with relevant actors in the processes of institutional change, with balanced representation, from the corporate sector, the four sectorial business associations that are relevant for Brazilian software industry, the Executive and the Legislature Powers. Thus, we conducted 16 semi-structured interviews, lasting an average of one hour, with managers of companies in the sector, leaders, and former leaders of business associations; members of the Executive and Legislative Powers. Investigations with diachronic perspective often require the use of documentary research, especially when the study period is set in a past time that prevents or hinders the use of the interview or observation method. But even when it is possible to use the interview as a method, document research allows access to a range of additional information and serves the purpose of strengthening the validation of constructs and test hypotheses through a triangulation of sources. Among the 146 analysed documents, whether in printed form, either online, there are reports of companies and business associations; legislation on the software industry and services; records of deliberations of the Congress sessions on changes in legislation; press articles, books, and articles on the subject, among other types and sources. The transcribed interviews and documents were processed by the technique of content analysis, a process of categorizing qualitative textual data into clusters of similar entities or conceptual categories that "identify consistent patterns and relationships between variables and themes". ${ }^{27}$ We employed the software N-Vivo 10 as a tool to support the analysis process. Content analysis followed the basic steps suggested by Bardin: ${ }^{28}$ pre-analysis; exploration of the material; treatment of the results and the interpretation. Content analysis of primary and secondary research data relating to the institutional change process studied in this article served two fundamental purposes. The first was to reconstruct, from different points of view, the chronology of events that have characterized the process. To meet this purpose, the data received a first encoding, indicating the time of each of the events considered relevant. The second purpose of the analysis was to understand who were the protagonists of each of the processes of institutional entrepreneurship, as well as their motivations and strategies.

\section{The case of intellectual property in the software industry in Brazil}

The institutional framework change related to software intellectual property rights in Brazil can be situated in the 80 s and 90 s decades of the last century. We identified a change process that can be separated in two different movements, both largely motivated by external pressures: the threat of trade retaliation by the United States, in the $80 \mathrm{~s}$; and incorporation of the matter of intellectual property in the GATT agreements in the 90s. Below, we present a chronological narrative that recovers the evolution of intellectual property rights regarding software production in Brazil. Then we analyse the actions of institutional entrepreneurship considering their motivations and positions occupied by protagonists in the organizational field.

\section{The first movement: from the threats of trade retaliation to the Law of Software of 1987}

In the 70s, in the period of military dictatorship (1964 to 1984), a vision of having an endogenous IT industry in the country oriented public policies: the military government has adopted several measures restricting imports of IT products and fostered its production inside the country. Although the market protection policy has started in the 70 s, it only began to be institutionalized in the 80 s, with the creation of SEI-Special Secretariat of Informatics, linked to the National Security
Council - and the adoption of Information Technology Law in 1984. ${ }^{29}$

During the $70 \mathrm{~s}$ and early $80 \mathrm{~s}$, the market protection for IT hardware and software had the support of the military, the scientific and technological community as well as from the new born companies producing hardware. ${ }^{30}$ However, with the end of the dictatorship, there was a conjunction of factors that destabilized the political alliance supporting the endogenous production and market protection policy. Internally, the military, by returning power to civilians, lost political power. Moreover, the economic crisis of the early 80 s significantly reduced investments to research and development in computer science in the country, reducing therefore the importance and influence of the scientific and technological community engaged on the government policy for the sector. However, the national hardware industry and the nascent software industry as well as most members of Congress and the Government kept their support to the policy of market protection.

Globally, the production of software was growing and increasingly representing a profitable business. The revenues from software, only on the domestic U.S. market, jumped from 6.5 billion dollars in 1975 to 40.7 billion in $1985 .^{31}$ The rapid growth of demand and lack of legal protection to software developers, associated with the loss of competitiveness of the U.S. economy in the early 80 s, are reasons to explain why large multinational companies, almost all with headquarters in the United States, had aimed to have free access to the Brazilian market. Additionally, there was the risk of Brazilian software industry to use reverse engineering to produce similar softwar. ${ }^{30,32,33}$ Indeed, the development of computer systems inspired on software from U.S. companies freely happened in Brazil in the 80s. For example, the Brazilian company Scopus commercialized SISNE, an operating system that was like MS-DOS, from Microsoft. In turn, the Brazilian company Cobra produced Sox, an Unix-based software.

In 1985, under pressure from companies like Microsoft and IBM, as well as business entities that supported the global movement to promote intellectual property rights, such as the International Intellectual Property Alliance (IIPA), the U.S. government announced the start of an investigation into the Brazilian informatics policy in accordance with section 301 of the U.S. Trade Act, that provides the possibility of applying trade sanctions in cases in that the United States considers that the business practices of a country are harmful to American interests. ${ }^{30}$ The measure had as main target the Brazilian software industry, protected by the market reserve then in force. Between 1985 and 1988, several meetings were held between officials from Brazil and the United States to resolve the trade dispute. During this period, the U.S. government threatened to overtax Brazilian products exported to the United States, such as shoes and orange juice, with the purpose of persuade the Brazilian government to repeal legislation that, in their view, harmed the software industry from USA.

During that period, support for the market reserve started gaining opponents also inside Brazil. Among them, other industrial sectors, which were in danger of suffering penalties for the protections continuity, but also companies that claimed to be losing competitiveness because they could not buy foreign, cheaper, and more efficient software..$^{33}$ These national companies were added to the chorus of subsidiaries of the multinationals from the software sector such as Microsoft and IBM. The debt crisis experienced by Brazil also led to an internal division in the Brazilian government, with ministries such as the one of Finance and Foreign Trade had understood that the market reserve, at the time, harmed the negotiations between Brazil and the United States government and with the International Monetary Fund. ${ }^{30}$ 
Amid the negotiations, the Brazilian government sent, in December 1986, a bill to the Congress that included one of the main points of the demand of the U.S. government: it was the Law of Software that proposed a system of protection of the software intellectual property rights. The Brazilian Congress approved this law in June, 1987 after discussions that showed a division between two representative business associations from the software sector in Brazil: Association of Brazilian Information Technology Companies (ASSESPRO) and the Brazilian Software Firms Association (ABES). In the one hand, ASSESPRO, a business association that gathers only national firms, did not opposed to protection of intellectual property rights, but expressed the wish that the law maintained a differentiated treatment to domestic firms. In the other hand, ABES, that had been created in 1985 and has defended the interests of multinational companies, was in favour of the new law and argued that it should be no legal provisions that would prevent or hamper the commercialization of software from foreign companies in Brazil. The final text of the Law 7.647/87 met only partly the interests of the U.S. government and foreign companies. In compliance to the demand of the U.S. government, the software started having copyright protection for 25 years. However, other articles of the law were aligned with the market reserve policy. To have copyright protection, the software needed to be registered before at the SEI - Special Secretariat of Informatics. Moreover, in relation to software from foreign companies, only those who had not similar in Brazil could be registered. Finally, software sales, both domestic and foreign, could only be held by domestic firms.

As soon as the law was enacted in December 1987, the United States suspended the threat of economic sanctions to Brazil, but did not end the case opened in 1985. New battles began to be fought, this time around the regulation of the law, especially about the criteria to be adopted to define if foreign software had or not a Brazilian similar. ASSESPRO, protecting the interests of domestic companies, defended the proposal to be consulted in the analysis of similarity. ${ }^{30}$ However, organizations such as the ABES, Industry federation form São Paulo (FIESP) and Brazilian Exporters Association have proposed that, to be considered similar, the software should have $95 \%$ of similarity in performance criteria quantitatively measured, to operate on the same types of equipment, instruments and peripherals, and to produce the same results in their core functions. Most of the claims that came from the group of business associations formed by ABES and FIESP were accepted by the government and incorporated into the Decree 96.036/88. ASSESPRO condemned the government's decision, arguing that the criteria incorporated in the decree would damage the nascent domestic industry. Thus, commercialization was the remaining aspect under market reserve with the new Software Law. The decree regulating the Law of Software, SEI, denied in June 1987 the application for commercialization in Brazil MS-DOS system, from Microsoft. However, this position was revised in January 1988, authorizing the commercialization of the version 3.3 of this operating system. In February 1988, the U.S. government announced the suspension of retaliatory measures, and, in the following year, closed investigations into Brazilian trade practices in software. The influence of the United States government in this significant institutional change is acknowledged in several studies about the episode..$^{30,32,33}$

The second movement: from the trade related aspects of intellectual property rights (trips) agreement until the law of software of 1998

The notion of intellectual property exists, with different interpretations, since antiquity. However, it only began to appear in regulation of international trade spotlight from the 80 s on, when trade of goods, factories and work began to be replaced by a knowledge economy, based on owner control of algorithms, genes, formulas, and other abstract objects. ${ }^{32}$ The pressure exerted by U.S. companies and business associations was initially directed to the inclusion of the issue of intellectual property rights in the strategies of bilateral trade negotiations between the United States and its trading partners. And indeed, during the $80 \mathrm{~s}$ and early $90 \mathrm{~s}$, the U.S. government opened investigations against several countries, accusing them of not respecting the intellectual property rights of major software companies of the United States, as happened in relation to Brazil between 1985 and 1989. However, this strategy required a great deal of negotiation. A second stage was the creation of international standards to arrange intellectual property right into international trade rules for all countries who participated in the GATT-General Agreement on Tariffs and Trade.

To ensure that the intellectual property rights of software will become law in all countries associated with the GATT, the first step undertaken by the United States government representatives was to convince his closest allies, in the European Union and Japan, that took place without major mishaps after a few rounds of negotiations, restricted to those countries in the $80 \mathrm{~s}^{32}$ After writing a proposal that pleased these partners, it came time to propose The Agreement on Trade Related Aspects of Intellectual Property Rights (TRIPS) of the Uruguay Round of GATT. Reports of meetings that culminated in the adoption of the U.S. proposal indicate that the subject of intellectual property faced little resistance from developing countries. This low resistance has some explanations. First, the United States, Europe and Japan presented the topic of intellectual property as a point that should necessarily be accepted; otherwise the Uruguay Round of GATT would be concluded without agreement. Moreover, the countries that opposed the proposal, such as Brazil and India, knew they would continue facing trade retaliation by the United States if they opposed the agreement. As the products protected by intellectual property rights used to not be the most relevant items traded by developing countries, and the acceptance of the proposed TRIPS Agreement opened the possibility of bargaining advantages over other items, such as agriculture or textiles, the U.S. proposal ended being victorious. Thus, since the closure of the Uruguay Round in 1994, any country wishing to join the WTO would need to adapt their domestic legislation to ensure the intellectual property of products such as software and medicines, in compliance to the standard approved by the 111 countries that have signed the agreement.

The TRIPS Agreement deals with the applicability of basic GATT principles and international agreements on intellectual property; stipulated the rights of intellectual property deemed appropriate; determined measures considered effective to enforce those rights; predicted mechanisms for multilateral dispute settlement. ${ }^{34}$ Regarding software, the agreement determined that this should become protected in the same way that literary works, for a period not less than 50 years, not allowing any form of preferential treatment for national and foreign products. The involvement of companies and business associations was decisive for the protection of intellectual property rights were guaranteed in the GATT Agreements. ${ }^{32}$ In the early 80 s, there was direct participation of large companies was greater. The advisory committee for United States government's trade policy had as its coordinator the CEO of Pfizer for a term. Companies like IBM and DuPont were also directly involved in the beginning of negotiations of the TRIPS Agreement, still in the 80s. In the software area, in addition to IBM, also Apple, Microsoft and Lotus actively participated. ${ }^{32}$ But gradually the direct participation of companies began to be replaced by business 
associations, representing the interests of U.S. multinationals and leading efforts to promote the globalization of intellectual property. Examples of such entities are the Intellectual Property Committee (IPC), the International Intellectual Property Alliance (IIPA) and the Business Software Alliance (BSA). Due to the technical nature of intellectual property, the analysis and lobbying use to end up under the responsibility of these associations. ${ }^{32}$ The IPC aggregated companies like DuPont, General Electric, General Motors, Heweltt-Packard, IBM, Monsanto, Pfizer, among other multinational corporations. The IIPA, in turn, brings together several business associations such as the American Film Marketing Association, Association of American Publishers and the Business Software Alliance, the latter bringing the leading software companies in the United States. The importance of the IPC is evident at the fact that it was this organization that drafted the document that served as a reference to the TRIPS Agreement. Moreover, this association and the others, at that time, maintained close relations with the Government and Congress of the United States, to shape the proposals and positions of that country during the negotiations of the TRIPS Agreement. ${ }^{32}$

In Brazil, legislation on intellectual property rights of software needed to be adjusted to comply the TRIPS Agreement, but before the Final Act of the Uruguay Round of GATT needed to be ratified by the Brazilian Congress. The Brazilian government sent to the Congress in June 1994, the Final Act of the Uruguay Round of Multilateral Trade Negotiations. In accelerated proceeding, the matter was discussed and approved by the Chamber of Deputies and the Senate in early December of that year, having been converted into legislative decree on December 16. The instrument of ratification was deposited in the GATT in Geneva on December 20. At the Congress, the then foreign minister, Celso Amorim, represented the government, highlighting the benefits of the agreement for Brazil, as the average reduction of import tariffs in developed countries, the elimination of non-tariff barriers such as import quotas, greater openness of international markets to the commercialization of agricultural products, as well as the possibility of future trade disputes be judged by the WTO, decreasing the possibility of unilateral retaliation without fair arbitration. Minister Celso Amorim, in a speech to Congress on December 7, 1994, the postponement of the decision by Congress would not bring gains to the country, "partly because (...) you cannot change any of the terms of the agreement". ${ }^{35}$ Some congressmen deplored the restriction imposed to the Congress to adopt a selective position, accepting some and rejecting another part of the agreement. The rapporteur of the message from the Government to the Congress, congressman Diogo Nomura, admitted that the GATT agreement was negotiated in a disadvantageous manner to developing countries, given the pressure from industrialized countries, but recommended its adoption, since, otherwise, the Brazil would be "isolated in the international arena and subject to a discriminatory treatment". ${ }^{34}$

The disadvantage of the GATT Uruguay Round Agreements was emphasized in the speech by deputy Haroldo Lima: “(...) the possible benefits that developing countries could reap in agreements on agricultural and textile sectors are annulled at the prospect of monopoly of developed countries over the knowledge". ${ }^{35}$ This congressman and other members pointed out what, in their view, was a contradiction of the Uruguay Round of GATT: while agreements on material goods followed a liberalizing line, there was a hardening of commercial interactions of knowledge intensive goods, with a tendency to perpetuate a monopoly of developing countries on the intangible assets. The approval of the TRIPS Agreement obliged Brazil to adjust legislation on intellectual property of software that had entered into force there were only seven years. A few months later, precisely on March 9, 1995, as a matter of urgency, the Federal Government of Brazil sent to the Congress a bill that aimed to upgrade the protection of the intellectual property rights of computer systems. In the justifications of the bill and in the discussions in Congress, there were concerns regarding the realignment of legislation on intellectual property right of the software in the light of another institutional change much broader scope: the end of the market reserve for IT products that lasted from 70 s to early 90 s. Eliminated the barrier to the commercialization of software produced abroad, there would be no reason for the copyright protection discriminated computer systems as to their origin, as was the law on the theme of 1987. Another important reason for the change was Brazil's adherence to TRIPS on the Uruguay Round of GATT that, as stated in the explanatory memorandum of the bill, has lagged legislation on the subject then in force. The rapporteur of the bill in the Committee on Constitution, Justice, and Citizenship (CCJ), Senator Lucio Alcantara, said, in relation to proposed amendments to the bill by the opposition, that they would be antagonistic "to the commitments assumed by the Brazil to the international community ${ }^{36}$ Thus, the subscription of Brazil to GATT was presented as an argument that forced Brazil to adapt their domestic law to the parameters of a recently completed international trade agreement that had, as one of its main themes, the international standardization of intellectual property rights. Another argument concerned the high rates of software piracy, between 68 and $75 \%$, per different statements from congressmen at the time of voting of the new law. The high rates of piracy brought two consequences, as suggest declarations presented in the explanatory memorandum of the project and discussion on the House of Representatives: 1) disincentive to research and development by firms; 2) high tax evasion.

The main changes proposed in the new bill, compared to the 1987 law, are:

a) The system of granting intellectual property rights for software became the same as the one granted to literary works, rising from 25 to 50 years

b) Software piracy started to be considered a crime of tax evasion, enabling the Federal Revenue Office to investigate companies and copies of software used in microcomputers

c) The penalties for those responsible for software piracy were increased

d) The obligation to register the software at SEPIN to obtain the license for the commercialization of software in the country has been eliminated

e) The restriction that only domestic companies could sell software in Brazil was eliminated.

The testimony of leaders and former leaders of business associations, as well as the documentary material examined indicate that only ABES among the existing sectorial business associations expressed formal support for the new law, even when it was still a project in Congress. ABES established in 1986 presented itself as an alternative to ASSESPRO that had existed since 1976 and had brought together only national software companies. ABES while representing national companies of different sizes, welcomed multinational companies such as Adobe Systems, Microsoft, IBM, Dell, Corell, Intel and Symantec. Testimonials from directors of ABES and documents of the entity show the Software Law 1998 as an achievement of the entity, but we did not find documentary evidence to support that this entity has 
exercised significant influence over the government and Congress. At the level of companies, documentary data and interviews indicate that Microsoft the advocated for the law approval, posting notes to support the change in legislation on their website. ${ }^{37}$

In the discussions in Congress, as happened in the vote of the Uruguay Round of the GATT, there were expressions of concern about the consequences of the new law on domestic firms. In a session held on January 21, 1998, Senator Roberto Requião, rapporteur of the bill in the Senate, said: "We will vote on the project, tied to Government's intention that is subjected to the interests of some multinational groups. This is the Bill Gates' project, who does not respect the consumer (...). ${ }^{38}$ On the other hand, supporters of the proposal by the Government argued that imposing a shorter term than 50 years for the rights of intellectual property of software or imposing requirements for recognition of rights of foreign manufacturers are in contradiction with the agreements of the GATT and the IT policy that the country had been using since the early 90 s, after the end of market protection. They also argued that the rights granted also benefit domestic software producers, stimulating the innovative capacity of Brazilian companies. Despite the restrictions of oppositionists, many of these voted for the bill, even though its amendments have been defeated. At a meeting on February 4, 1998, the project that had been modified by the Senate passed the House of Representatives and was then sent to the Executive Branch that sanctioned it, transforming it into law on February 19 of that year. Table 2 presents a framework that summarizes evolution of intellectual property evolution in software industry in Brazil. In the next section, we discuss the changes in intellectual property.

Table 2 Chronological summary of the process of institutional change regarding to intellectual property of software

\begin{tabular}{|c|c|}
\hline Month/Year & Event \\
\hline Sep-85 & Initiation of investigations by the United States Government relating to the Brazilian market reserve for IT products. \\
\hline 1986 & Establishment of the Intellectual Property Committee (IPC). \\
\hline Sep-86 & Start of the Uruguay Round of GATT \\
\hline Sep-86 & Creation of ABES - Brazilian Association of Software Companies \\
\hline Dec-86 & Submission of the Project of Law of Software (Law No. 7.647/87) by the Government to the Congress. \\
\hline Jun-87 & Rejection, by the SEI, of application for commercialization of MS-DOS system, from Microsoft, in Brazil. \\
\hline Nov-87 & Announcement of U.S. trade retaliation against Brazil for disregard for intellectual property and protectionist policy in the IT field. \\
\hline Dec-87 & Congressional approval of the Software Law (Law No. 7.647/87). \\
\hline Dec-87 & Presidential assent to the Software Law (Law No. 7.647/87). \\
\hline Jan-88 & Approval, by the SEI, of application for commercialization of MS-DOS system, from Microsoft, in Brazil. \\
\hline Feb-88 & Announcement of the suspension of U.S. trade retaliation against Brazil. \\
\hline Mar-88 & Establishment of the Business Software Alliance (BSA). \\
\hline May-88 & Publication of procedures for implementation of Law No. 7.647/87: Decree 96.036/88. \\
\hline Oct-89 & Archiving of investigations by the United States relating to the Brazilian market reserve for IT products. \\
\hline Apr-94 & Closure of the Uruguay Round of GATT, that contained the TRIPS Agreement. \\
\hline Jul-94 & Submission by the Government to the Congress of the Uruguay Round Final Act. \\
\hline Dec-94 & Congressional approval of the Final Act of the Uruguay Round (Legislative Decree 449/94). \\
\hline Jan-95 & Entry into force of the agreements of the Uruguay Round of GATT, including the TRIPS Agreement. \\
\hline Mar-95 & Submission by the Government to the Congress of the Bill $200 / 1995$, that deals with intellectual property protection of computer programs. \\
\hline Feb-98 & Approval of Software Law (Law No. 9.609/98) in Congress. \\
\hline Feb-98 & Presidential assent to the Software Law (Law No. 9.609/98). \\
\hline
\end{tabular}

\section{Analysis}

The changes in the Brazilian legislation regarding intellectual property of software can be considered as one project of an international program aimed at institutional homogenization. This understanding comes from an analysis of the case that considers essentially the motivating forces of institutional entrepreneurship, as well as the positions occupied by the main actors involved in the organizational fields.

\section{Conditions of the organizational field: uncertainty,} tensions, and contradictions

The process of institutional change on intellectual property of software in Brazil describes an organizational field with global coverage and another field with national boundaries. Some actors correspond to both fields, but what happens in the global field severely restricts the possibilities of action of actors in the local scene. The relationship between the two fields is not stable throughout the process, evolving as the protagonists of the changes in the global field performed their project of institutional change. The organizational field of global reach has, as actors, large U.S. companies that encountered obstacles to their growth because of non-recognition, in many countries, of the rights of intellectual property on products like software, pharmaceuticals, and genetically modified foods. These companies have sought support from the United States Trade Representative's office (USTR), the government agency in charge 
of U.S. foreign trade policy, and in the U.S. Congress. Initially this support took the form of threats of trade retaliation in a bilateral relationship of the United States Government over countries suspected of not securing the intellectual property rights on products from these companies or imposing restrictions on their entry into their domestic markets. As the disputes over intellectual property were developed in tense bilateral relations, these companies sought support from the United States Government to create and disseminate a global model for the protection of intellectual property rights that would favour their business interests that began to be accomplished in the Uruguay Round of GATT in 1986. From that moment on, business associations such as the International Intellectual Property Alliance (IIPA), the Intellectual Property Committee (IPC) and the Business Software Alliance (BSA), created respectively 1984, 1986 and 1988 took the leadership. ${ }^{39,40}$

Thus, in this case a broader organizational field was composed of large companies operating globally and business associations focused on intellectual property, the Government and Congress of the United States and the governments of countries threatened of commercial retaliation, as was the case of Brazil between 1985 and 1989. The field, that was already international, has become truly global from the moment that the harmonization of intellectual property came into discussion in the GATT between 1986 and 1994. In this scenario, the IPC played a prominent role because this entity wrote the sketch of the proposal that, with minor adjustments, took the form of the TRIPS Agreement. Government representatives of almost all countries of the world were represented at the team, who participated in the discussions on this topic over eight years between the first and last meeting of the Uruguay Round of GATT. During the discussions, these countries were divided into blocks, with the U.S. taking Europe, Canada and Japan as allies and finding a weak resistance from developing countries like Brazil and India. Once signed the Agreement on Trade Related Aspects of Intellectual Property Rights, in 1994, and guaranteed the institutional harmonization on a global level, the organizational field persisted with the same actors, but with lower activity level as the large project, arisen about a decade earlier, had already been achieved. ${ }^{41}$

While the actors were acting on broader organizational field, their performances impacted on the actions that had been taking place on a parallel organizational field with more narrow boundaries represented by the nascent industry of software and services in Brazil. In this smaller organizational field, there was the participation of companies with domestic capital, but most were small. Initially, the protection of their interests was assumed by ASSESPRO. With the entry of foreign companies in the Brazilian market, conditions of this organizational field changed and emerged conflict between isomorphic tendencies and divergent tendencies related to the level of power of the different actors. ${ }^{17}$ ABES, a competing association with ASSESPRO was created to reinforce interest of multinational companies in the country. Moreover, Brazilian Government policies were changing and favoured compliance to multinational companies' interests, giving room for a renew position regarding the former market reserve practiced in the military regime in the $70 \mathrm{~s}$ and $80 \mathrm{~s}$ decades in the last century. Nonsectorial national business associations, such as FIESP, reinforce the position of compliance to multinational companies' interests to avoid trade retaliation in other sectors and to decrease the higher costs of computer inputs. The Congress took part in the organizational field during the discussions on drafting a law that would modify the rules relating to intellectual property. From the moment that Brazil signed the Act of the Uruguay Round of GATT, the national actors who wished to maintain an institutional framework for the protection of the domestic software industry became powerless against the major change consummated globally and its power to restrict the decisions policies of each country.

We consider that from the standpoint of U.S. companies' heterogeneous organizational fields represented uncertainty as the existence of different rules per country was enabling practices as reverse engineering to produce competing software in addition to the problem of software piracy. To avoid uncertainty the project of institutional change at the global level replacing the heterogeneity by institutional homogeneity. This institutional heterogeneity was a motivating power of entrepreneurial effort, motivating the central actors in the organizational field to impose their preferred model to other actors. Thus, in the global dimension of this project of institutional change, there is support to the thesis that there of a tendency that heterogeneous organizational fields are more prone to episodes of institutional entrepreneurship. ${ }^{5,17}$ On the local scenery, institutions were pieces of a multi-coloured mosaic when one considers the planetary map of institutions about intellectual property of software that prevailed in the 80 s and early 90 s. Anyway, the main motivation for the creation of the first and second Law of Software in Brazil was not local, but came from outside.

\section{Position of the actors in the organizational field}

Hardy \& Maguire ${ }^{5}$ state that actors have no power, but they can occupy powerful positions in the organizational field, justifying the examination of the positions occupied by the main actors in the double organizational field where took place the process of institutional change regarding the intellectual property of software in Brazil. Per Greenwood \& Suddaby, ${ }^{16}$ the notions of centre and periphery covers the ability of the central actors in a social structure to establish an institutional logic favourable to their interests as well as the acceptance of this logic as given by the different members of the organizational field. The position of centrality is associated with the possession of resources, not necessarily financial. The legitimacy and ability to influence other individuals or organizations are resources that may be relevant too. ${ }^{5}$

In the case of intellectual property rights, one can recognize a gradual occupation of centrality by large companies in at the organizational field with global coverage. At this organizational field, multinational companies as Monsanto, DuPont, Novartis, General Electric, General Motors, Hewlett-Packard, IBM, Johnson \& Johnson, Merck, Warner Communications, Apple, and Microsoft have been interested in organizing a global standardization project of intellectual property. In this case, centrality and economic power are associated. Thus, an analysis of the position of the protagonists of institutional change in relation to its organizational field reveals that central actors act as institutional entrepreneurs, as proposed Fligstein. ${ }^{42}$ Large multinational companies in the software sector, allied to the United States Government, occupy a central position in the field, while the developing countries and their companies occupy peripheral position. At the organizational field with national boundaries, intuitional entrepreneurs' positions have not remained so stable throughout the process. During market reserve time, national IT companies and government kept the organizational field relatively homogeneous and protected from external movements. However, given external pressures (e.g. U.S. government and multinational companies), the local organizational field and its actors was gradually integrated to the organizational field with global reach. Brazilian Government support for national companies became increasingly less relevant when the 
national organizational field blurred to a broader one with global reach. This transformation in the local scenario becomes evident when the strong resistance to the first Law of Software, in 1987 is compared to the tenuous resistance to the second Law, in 1998. Eleven years after the decline of market reserve policy later, population of companies in IT industry in Brazil was of numerous national small software and a set of multinational companies. Nevertheless, the later occupying a central and powerful position regarding influence on the government to have the country aligned to international standards of intellectual property rights. In 1987 the large trade association from the software sector in Brazil was ASSESPRO, but in 1998 ABES occupied a central position representing the software sector with the support of large foreign companies such as Microsoft and IBM. Thus, when the national field was relatively protected from the global field, or when one field was absorbed into another, institutional entrepreneurs, those who made the greatest efforts to produce a new institutional arrangement, they not lived were in the periphery of their respective fields, confirming a trend observed in other studies of institutional entrepreneurship. ${ }^{17,43}$

\section{Conclusion}

The purpose was to investigate to what extent institutional entrepreneurship plays a role on the change of a formal institution as the intellectual property rights. We considered the evolution of intellectual property rights in the software industry in Brazil as an exemplar case to offer insights on the interplay between public and private sectors and national and international actors in the establishment of the rules of the game to be played in an industry. We focused on the characterization of the actors influencing institutional change, considering the following: (a) the conditions in an organizational field (b) the position held by institutional entrepreneurs in an organizational field. The analysis included the identification of the motivations of the process of institutional entrepreneurship, as well as the evaluation of possible relationship between the positions of the protagonists of process of change compared to the other actors in the same organizational field. The theoretical support for this study was taken mainly from the organizational institutionalism, backed by contributions of the institutional economics. Studies on the institutions have gradually abandoned a deterministic and unidirectional conception of its relationship with individuals and organizations, especially on light of the theoretical and empirical contributions that come from research on the institutional entrepreneurship. The results of this investigation align with this new perspective, revealing that, in addition to the great power that institutions have over the organizations, these also have, under certain circumstances, power to shape their institutional environment according to their interests.

Indeed, examination of the history of the software and services industry in Brazil over a period of about 20 years has shown that institutions have shaped the industry and influenced the survival of certain organizations and the extinction of others. But it also showed that, acting collectively; organizations can promote changes in institutions, getting rid of the condition of being inert victims of their environment, a finding like what had been observed in other studies on the subject. $2,6,26,42,44$

The examination of the process of institutional change on intellectual property of software revealed a complex interaction between two organizational fields, one local and another global. Initially protected from external threats, the local organizational field has set of institutions that legitimate practices as software reverse engineering that has been condemned in the global organizational field. The local organizational field began to erode in the face of increasing pressure from external actors, in the global field, that had much more power, exerting threats of trade retaliation, and including intellectual property as a commercial agreement of GATT. The analysis of the characteristics of the organizational fields involved in this process of institutional change shows the existence of multiple and contradictory institutions as has been pointed out, in the literature on institutional entrepreneurship, as a feature of the organizational fields that is favourable to the emergence of projects of institutional change. ${ }^{10,17,21}$ Contradiction motivated the central actors in the organizational field to impose their preferred model to other actors. In the context of intellectual property, institutional diversity was an obstacle to the project of creation of a global market dominated by the largest companies that motivated them to organize a project of institutional homogenization. ${ }^{45,46}$

In this process of institutional change, we have also identified that institutional change was not conceived in the periphery but at the centre of global organizational field, by the more powerful actors and that, after the consummation of the change, reached an even more dominant position. This finding is consistent with the results of other studies that identify the actors with more resources as the protagonists of processes of institutional entrepreneurship. ${ }^{16,40,41}$ This, however, is a matter of debate within the organizational institutionalism as there are studies that show institutional entrepreneurship projects can be led by peripheral actors, who would have the motivation to make changes, given the trend that the existing institutional arrangements do not meet primarily these actors. ${ }^{5,8,16}$ It must however be remembered that the desired institutional change involved, in the case study, a change in legislation and had to have government support to be implemented. One possible explanation for the fact that the protagonists were powerful actors is linked to the need to mobilize large amounts of resources to support business associations and fund studies aiming to provide technical support to a political demand. Studies on institutional entrepreneurship can explore, in other contexts, the conditions that are necessary for less powerful actors become protagonists in episodes of institutional entrepreneurship. ${ }^{47-51}$

The findings and conclusions presented here should be considered taking into account the limitations of this research work. First, the study considers an institutional change in a developing economy. The dynamics of the relationship between organizations and institutions may have significant differences in other contexts. Furthermore, we followed the bias of success, present in almost all the studies on institutional entrepreneurship, that exploit successful cases of institutional change, ignoring the empirical and theoretical richness that can come from the study of experiences that resulted in failure. The obtained results suggest opportunities for further investigation. The intellectual property laws on the software adopted in Brazil in 1987 and 1998 appeared as processes of institutional change largely determined by an institutional project on a global scale. If it is true that the inclusion of intellectual property rules in the GATT agreements led to an institutional homogenization, then we should find, in other countries, and in the same period, parallel movements to the Brazilian one. A study comparing the evolution of the intellectual property laws of the software in different countries may reveal the similarities and peculiarities of the adaptations of each country in the face of the strength of this process of institutional harmonization. Furthermore, studies comparing the positions of institutional entrepreneurs compared to the other actors in their organizational fields in change processes of formal and informal institutions can help clarify whether there is an association between the type of institution to be transformed and the amount of resources required for the entrepreneurial effort to be successful. 


\section{Acknowledgment}

None.

\section{Conflicts of interest}

The author declares that no conflicts of interest exist in publishing this article.

\section{References}

1. ABES. Mercado brasileiro de software: panorama e tendências. São Paulo: ABE -Associação Brasileira das Empresas de Software; 2013.

2. Battilana J, Lecca B, Boxenbaum E. How Actors Change Institutions: Towards a Theory of Institutional Entrepreneurship. The Academy of Management Annals. 2009;3(1):65-107.

3. Colomy P. Neofunctionalism and neoinstitutionalism: human agency and interest in institutional change. Sociological Forum. 1988;13(2):265300 .

4. Fligstein Neil. The Architecture of Markets: An Economic Sociology of Twenty-First-Century Capitalist Societies. Princeton: Princeton University Press; 2001.288 p.

5. Hardy, Cynthia, Maguire, et al. Institutional entrepreneurship. In: Greenwood, Royston, editors. Handbook of Organizational Institutionalism. London: Sage Publications; 2008. 558 p.

6. DiMaggio, Paul. Interest and Agency in Institutional Theory. In: Zucker, Lynne G, editors. Institutional Patterns and Organizations. Cambridge: Ballinger Publishing Company; 1988. 225 p.

7. Greenwood R, Suddaby R. Institutional Entrepreneurship in Mature Fields: The Big Five Accounting Firms. Academy of Management Journal. 2006; 49(1):27-48.

8. Leblebici H, Salancik GR, Copay A, et al. Institutional change and the transformation of interorganizational fields: an organizational history of the U.S. Radio broadcasting industry. Administrative Science Quarterly. 1991;36(3):333-363.

9. Giddens Anthony. A constituição da sociedade. São Paulo: Martins Fontes; 2009.185 p.

10. Beckert J. Agency, Entrepreneurs, and Institutional Change. The Role of Strategic Choice and Institutionalized Practices in Organizations. Organization Studies. 1999;20(5):777-799.

11. Veblen, Thorstein. The Theory of the Leisure Class: an economic study in the evolution of institutions. New York: Macmillan; 1899. 184 p.

12. Levy D, Scully M. The institutional entrepreneur as modern prince: the strategic face of power in contested fields. Organization Studies. 2007;28(7):971-991.

13. Maguire S, Hardy C, Lawrence TB. Institutional entrepreneurship in emerging fields: HIV/Aids treatment advocacy in Canada. Academy of Management Journal. 2004;47(5):657-679.

14. Eisenstadt SN. Institutionalization and Change. American Sociological Review. 1964;29(4):235-247.

15. Pfeffer Jeffrey, Salancik Gerald R. The external control of organizations: a resource dependence perspective. Stanford: Stanford University Press; 2003. 598 p.

16. Greenwood R, Suddaby R, Hinings CR. Theorizing change: the role of professional associations in the transformation of institutional fields. Academy of Management Journal. 2002;45(1):58-80.

17. Seo MG, Creed WED. Institutional contradictions, praxis, and institutional change: a dialectical perspective. Academy of Management Review. 2002;27(2);222-247.
18. Meyer JW, Rowan B. Institutionalized organizations: formal structure as myth and ceremony. American Journal of Sociology. 1997;83(2):340 363.

19. DiMaggio PJ, Powell WW. The Iron Cage Revisited: Institutional Isomorphism and Collective Rationality in Organizational Fields. American Sociological Review. 1983;48(2):147-160.

20. Scott Richard W. Institutions and Organizations: Ideas, Interests and Identities. Thousand Oaks: SAGE; 1995. 22 p.

21. Hoffman AJ. Institutional evolution and change: environmentalism and the U.S. chemical industry. Academy of Management Journal. 1999;42(4):351-371.

22. Bourdieu Pierre. The forms of capital. In: Richardson, John G, editors. Handbook of Theory and Research for the Sociology of Education. Westport: Greenwood Press; 1986. 258 p.

23. Lawrence Thomas B. Power, Institutions and organizations. In: Greenwood, Royston, editors. Handbook of Organizational Institutionalism. London: Sage Publications; 2008. 427 p.

24. Roberts, Peter W. Charting Progress at the Nexus of Institutional Theory and Economics. In: Greenwood, Royston, editors. Handbook of Organizational Institutionalism. London: Sage Publications; 2008. 385 p.

25. Pacheco DF, York JG, Dean TJ, Sarasvathy SD. The coevolution of institutional entrepreneurship: a tale of two theories. Journal of Management. 2018;36(4):974-1010.

26. Rodrigues, Suzana B Child, John. Corporate co-evolution: a political perspective. Chichester: John Wiley \& Sons Ltd; 2008. 325 p.

27. Julien Heidi. Content Analysis. In: Given, Lisa M, editors. The Sage Encyclopedia of Qualitative Research Methods. Thousand Oaks: SAGE Publications; 2008.721 p.

28. Bardin Laurence. Análise de conteúdo. Lisboa: Edições; 1977. 5 p.

29. Schmitz, Hubert, Cassiolato, et al. Hi-Tech for Industrial Development: Lessons from the Brazilian Experience in Electronics and Automation. New York: Routledge; 1992. 256 p.

30. Bastos Maria-Ines. Winning the Battle to Lose the War? Brazilian Electronics Policy Under US Threat of Sanctions. Ilford, Essex: Frank Cass and Company Limited; 1994. 18 p.

31. Steinmueller W. Edward. The US software industry: an analysis and interpretive history. In: Mowery, David $\mathrm{C}$, editor. The International Computer Software Industry. New York: Oxford University Press; 1996. $75 \mathrm{p}$.

32. Braithwaite John, Drahos Peter. Global Business Regulation. Cambridge: Cambridge University Press; 2000. 722 p.

33. Schmitz Hubert, Hewitt Tom. Uma avaliação da reserva de mercado na indústria Brasileira de computadores. Ensaios FEE. 1992;13:131-165.

34. Lampreia, Luiz Felipe Palmeira. Resultados da rodada Uruguai: uma tentativa de síntese. Estudos Avançados. 1995;9:247-260.

35. Brasil. Diário do Congresso Naciona. 1994.

36. Agência Senado. Proteção da Propriedade de Software É Aprovada na CE e Vai ao Plenário na Quinta. 1998.

37. Microsoft. Presidente Fernando Henrique Cardoso sanciona nova Lei de Software. 1998. 25 p.

38. Brasil. Diário do Senado Federal. 1988.

39. Siwek Stephen E. Copyright Industries in the U.S. Economy: the 2013 report. Washington: International Intellectual Property Alliance (IIPA); 2013. 26 p. 
40. Morris Joseph. Software Industry Accounting. New Jersey: John Wiley \& Sons; 2001. 624 p.

41. Drahos P. Securing the Future of Intellectual Property: Intellectual Property Owners and their Nodally Coordinated Enforcement Pyramid. Case Western Reserve Journal of International Law. 2004;36(1)3:53-78.

42. Fligstein N. Markets as politics: a political-cultural approach to market institutions. American Sociological Review. 1996;61(4): 656-673.

43. Rao H, Monin P, Durand R. Institutional change in Toque Ville: nouvelle cuisine as an identity movement in French gastronomy. American Journal of Sociology. 2003;108(4):795-843.

44. Flier B, Van Den Bosch FAJ, Volberda HW. Co-evolution in strategic renewal behavior of British, Dutch and French financial incumbents: interaction of environmental selection, institutional effects and manageria intentionality. Journal of Management Studies. 2003;40(8):2163-2187.

45. Williamson OE. The new institutional economics: taking stock, looking ahead. Journal of Economic Literature. 2000;38(3):595-613.
46. Hodgson GM. What are institutions? Journal of Economic Issues. 2006;40(1):1-25.

47. Holm $P$. The dynamics of institutionalization: transformation processes in Norwegian fisheries. Administrative Science Quarterly. 1995;40(3):398422.

48. Jepperson Ronald L. Institutions, institutional Effects, and Institutionalism. In: Powell WW, DiMaggio P, editors. The New Institutionalism in Organizational Analysis. Chicago: The University of Chicago Press; 1991. 486 p.

49. Munir Kamal A, Phillips Nelson. The birth of the 'Kodak moment': institutional entrepreneurship and the adoption of new technologies. Organization Studies. 2005;26(11):1665-1687.

50. North Douglass C. Institutions, Institutional Change and Economic Performance. Cambridge: Cambridge University Press; 1990. 23 p.

51. Sell Susan K. Private Power, Public Law: The Globalization of Intellectual Property Rights. Cambridge: Cambridge University Press; 2003. $24 \mathrm{p}$. 